\title{
Physical Factors in Age-Related Physical Performance Decline in Older Adults at Lembaga Lansia Indonesia, West Java Branch
}

\author{
Vitriana, Irma Ruslina Defi \\ Department of Physical Medicine and Rehabilitation Faculty of Medicine Universitas Padjadjaran \\ Dr. Hasan Sadikin General Hospital Bandung, Indonesia
}

\begin{abstract}
The aging process is associated with increased body fat and decreased muscle mass and strength in older adults. This condition is frequently associated with loss of mobility and functions. This study aimed to explore the relationship between physical performance and handgrip strength, body composition, and anthropometry in community-dwelling older adults living in Bandung, West Java Province, Indonesia. A cross-sectional study was performed from December 2015 to June 2016 on community-dwelling older adults above 60 years old who were the members of the West Java Branch of Lembaga Lansia Indonesia, Indonesia, with the ability to walk without an assistive device and to perform hand grip properly as an additional inclusion criterion. Subjects were excluded if they experienced severe cardiorespiratory or vascular abnormalities, used artificial implants, underwent hormone therapy, and had any disease that would affect the accuracy of the variable measurement. A total of 106 subjects (60-85 years old) participated in this study. A significant negative correlation between total body fat and physical performance and a positive correlation between handgrip strength to physical performance were observed among subjects. However, no correlation was found between the anthropometric measurement and physical performance. The total body fat percentage, muscle mass index, and handgrip strength correlate significantly to the physical performance in older adults and may be used as a good indicator to preserve physical function and quality of life in the elderly.
\end{abstract}

Key words: Anthropometry, body fat, muscle mass index, older adults, physical performance

\section{Faktor-Faktor Fisik yang Memengaruhi Penurunan Performa Fisik Lanjut Usia di Lembaga Lansia Indonesia Cabang Jawa Barat}

\begin{abstract}
Abstrak
Proses penuaan sering dihubungkan dengan peningkatan lemak tubuh yang disertai dengan berkurangnya massa dan kekuatan otot pada lanjut usia. Kondisi ini sering berkaitan dengan hilangnya kemampuan mobilisasi dan fungsi lainnya. Tujuan penelitian ini adalah melihat hubungan antara performa fisik dengan kekuatan genggam tangan, komposisi tubuh dan antropometri pada komunitas lanjut usia yang tinggal di Bandung, Jawa Barat, Indonesia. Penelitian potong lintang dilakukan periode Desember 2015 sampai dengan Juni 2016 pada lanjut usia yang tinggal dalam komunitas dan merupakan anggota Lembaga Lansia Indonesia Cabang Jawa Barat, berusia lebih dari 60 tahun, serta mampu berjalan tanpa alat bantu dan dapat menggenggam tangan dengan baik. Partisipan dieksklusi bila menderita gangguan kardiorespirasi atau vaskuler yang berat, menggunakan implan artifisial, menjalani terapi hormonal dan mempunyai penyakit yang berpotensi mempengaruhi akurasi penilaian variabel. Dari total 106 partisipan dengan rentang usia 60-85 tahun, ditemukan korelasi negatif antara total lemak tubuh dengan performa fisik, dan korelasi positif antara kekuatan genggam tangan dengan performa fisik, akan tetapi tidak ditemukan hubungan antara komponen antropometri dengan performa fisik. Persentasi total lemak tubuh, indeks massa otot dan kekuatan tangan mempunyai hubungan yang bermakna dengan performa fisik pada lanjut usia dan dapat menjadi indikator yang baik dalam mempertahankan fungsi fisik dan kualitas hidup pada lanjut usia.
\end{abstract}

Kata kunci: Antropometri, indeks massa otot, lanjut usia, lemak tubuh, performa fisik

Corresponding Author: Vitriana, Department of Physical Medicine and Rehabilitation Faculty of Medicine Universitas Padjadjaran/Dr. Hasan Sadikin Hospital Bandung, Indonesia, Jalan Pasteur No 38 Bandung, West Java, Indonesia, Email: vitriana02@gmail.com 


\section{Introduction}

Physical functioning is considered to be the main determinant of quality of life and is essential to maintain independence and daily tasks among the elderly. One key component in healthy aging is maintaining an adequate physical performance level, which can be measured by assessing the average walking speed of older adults. Walking speed is a simple physical performance measurement that can be a "vital sign" to assess the elderly health risks and needs in a clinical setting. ${ }^{1}$ Various detrimental conditions, including poor general health, mobility impairment, impaired physical and cognitive performance, accidents, aging, lack of freedom, and death, are linked with slow walking speed. ${ }^{1}$

Walking speed is known to be influenced by modifiable and unmodifiable factors, one of which is ethnic differences. ${ }^{2}$ In a study of older Mexican Americans and European Americans, walking speed could be fully explained by contextual (i.e. age, sex, education, income), lifestyle, or anthropometric factors (i.e. body mass index, height, and physical activity) without considering diseases and impairments. Ethnicity explained $20.3 \%$ of the variance in walking speed while the BMI, height, and physical activity explained $4 \%, 2.5 \%$, and $1.9 \%$ of the variance in walking speed, respectively. Both contextual and lifestyle/anthropometric factors explained $28.7 \%$ of the variance in walking speed. Other factors such as gender differences are among the factors that influence walking speed and gait cycle variation in elderly living independently in the community. ${ }^{3}$

Muscle strength is strongly associated with functional outcomes, mobility status, and mortality in older age than muscle mass. Many factors influence muscle strength. In a study of Japanese adolescents, muscle strength shows a relation between anthropometric and body composition. The result shows that in men, grip strength was positively correlated with height and lean body mass, in contrast to women, the positive relation was only found between grip strength and height. Body height is directly related to handgrip strength, possibly because this factor is more closely related to the lean body mass. Height and lean body mass are essential factors for grip and leg strength, especially for men. ${ }^{4}$

Obesity has become a major global public health as it has extended into developing countries. The prevalence of obesity and central obesity in the Indonesian adult population in general, according to the National Health Census in 2007, was $23.1 \%$ and $28 \%$, respectively. A significant difference exists between the percentage of males and females who have obesity and central obesity. The percentages of obese males and females are $16.9 \%$ and $28.6 \%$, while for central obesity, the percentages are $12.1 \%$ and $41.9 \%{ }^{5}$ A significant trend of obesity may increase the risk of impaired physical function and quality of life in the elderly.

Data from NHANES 1999-2004 found that both BMI and waist circumference were positively associated with all measures of functional disabilities. Adults with a BMI $\geq 30 \mathrm{~kg} /$ $\mathrm{m}^{2}$ aged 65 years and older had a $60 \%$ higher risk of incident disability, but it remains debatable whether body mass index is an appropriate measure of obesity in the elderly population. Alternatively, body composition is considered to be an important determinant of health and functioning in old age. The increase in fat and the decrease in lean mass can be observed even if there is no change in body weight and physical activity. These changes in body composition with age could lead to a restriction in activity participation and the ability to perform self-care tasks; thus, leading to functional limitations, dependency, and increased mortality in older persons. Only few studies investigated the relationship between specific body composition and physical function that the results are still even unclear. ${ }^{6}$

Most studies were conducted in communitydwelling older adults, predominantly Caucasian, only two studies included African-American population, and few studies were conducted in Asian populations. This study will evaluate the correlation of physical performance with muscle strength, body composition, and anthropometry which is an important milestone to detect a decrease of physical performance in a simple way that makes physicians design targeted interventions to maintain the overall functions of community-dwelling older adults, especially in Indonesia.

\section{Methods}

This study involved elderly sampled using the total purposive sampling approach from the population of elderly in Lembaga Lansia Bandung, West Java Province, Indonesia started from December 2015 until June 2016. This method was used to select participants in a non-random 
manner a sample of elements to represent a cross-section of the population. All participants were informed about the nature and purpose of the study and provided with written informed consent before participation. Inclusion criteria were older adults (60-90 years old), who were a member of Lembaga Lansia Indonesia, West Java Branch, lived in the community and were able to walk without an assistive device, could do the handgrip properly, and agree to participate in this study. Elderly with severe cardiorespiratory problems or cardiovascular abnormalities, using any artificial implant, undergoing hormone therapy, and suffering from other diseases that will influence body composition, functional performance, and accuracy of Bio-Impedance measurement were excluded in this study. This study had been approved by the Health Research Ethics Committee Faculty of Medicine of Universitas Padjadjaran (No.791/UN6.C1.3.2/ KEPK/PN/2015).

In this study, the physical factors (body composition and height) of the participants were measured and analyzed in terms of their relationship with the physical performance measured through assessment of walking speed (m/sec). Body composition evaluation was measured using a portable Body Impedance Analyzer (BIA, TANITA BC-601®, Tokyo, Japan). Data of body weight $(\mathrm{kg})$, body mass index $\left(\mathrm{kg} / \mathrm{m}^{2}\right)$, lean muscle mass $(\mathrm{kg})$, and body fat composition (\%) of participants were taken from BIA. The procedures of BIA were conducted by instructing the participants to stand upright barefoot on the electrode platform and hold the hand electrode with all fingers. Hand position was in full extension with a little abduction to avoid touching other parts of the body.

The height of the participants was measured using a stadiometer, while the strength of the muscle was measured using a handgrip dynamometer (JAMAR® 5030J1, Hydraulic Hand Dynamometer, Canada). Participants performed the test three times with the dominant hand, and the highest value was used in the analyses. Physical performance was evaluated using comfortable gait speed (m/second) that was measured by the 6-minute walk test, following the American Thoracic Society guideline.

Descriptive analysis was utilized for the characteristics of the participants. The p-value for numeric data was tested using unpaired t-test if normally distributed or with Mann Whitney test if data were not normally distributed. For categorical data, the p-value was measured using Kolmogorov Smirnov and Exact Fisher if the Chi-Square requirements were not fulfilled. Spearman Correlation Test or Pearson correlation coefficient (based on the type of variable) was performed to determine the association between physical performance, body fat, BMI, and muscle strength. The significance of the association was reflected by a p-value of less than 0.05 . Several statistical analyses were performed using the Statistical Package for the Social Sciences (SPSS) version 21.0 for Windows (IBM Corp., Armonk, NY, USA).

\section{Results}

A total of 106 older adults were recruited in this study (40 males, 66 females). The average age of the participants was $67.54 \pm 5.94$ years old, with a mean BMI categorized as overweight (23$24.9 \mathrm{~kg} / \mathrm{m}^{2}$ ) based on the Asian-Pacific cut-off points. The mean total fat was $29.96 \pm 7.33 \%$ or in the category of excess fat (30-40\%). However, when classified by gender, differences were identified in the characteristics between men and women (Table 1), except for age and physical performance.

Tables 2 and 3 show that body composition and muscle strength influenced physical performance. The study showed that there was a low negative correlation $(r=-0.360)$ between physical performance and body fat and, on the opposite, there was a positive correlation $(\mathrm{r}=0.210)$ between physical performance and skeletal muscle mass index. In both genders, physical performance had a positive correlation with handgrip strength (Table 3).

\section{Discussion}

Aging can lead to declined physical performance that can cause increases in physical disabilities. One of the primary causes of declined functional capacity is impaired mobility, which can be measured through walking speed. Usual gait speed (UGS), as one of the physical performance parameters, is recognized as a good indicator of various health conditions as well as a predictor of future disability and mortality. An earlier cohort study showed that the average walking speed of the elderly in a developing country is $0.81 \mathrm{~m} / \mathrm{s}-0.78 \mathrm{~m} / \mathrm{s}$ among women and 0.86 $\mathrm{m} / \mathrm{s}$ among men. ${ }^{7}$ This finding was similar to our study that found the average walking speed among women of $0.87 \pm 0.184 \mathrm{~m} / \mathrm{s}$, which was slightly different from men $(0.91 \pm 0.492 \mathrm{~m} / \mathrm{s})$ 
Table 1 Characteristic Differences Based on the Genders of Community-Dwelling Older Adults

\begin{tabular}{|c|c|c|c|}
\hline \multirow[b]{2}{*}{ Variables } & \multicolumn{2}{|c|}{ Gender } & \multirow[b]{2}{*}{ p-value } \\
\hline & $\begin{array}{c}\text { Male } \\
(n=40)\end{array}$ & $\begin{array}{l}\text { Female } \\
(n=66)\end{array}$ & \\
\hline Age (years) & & & 0.550 \\
\hline Mean \pm Std & $67.80 \pm 5.927$ & $67.21 \pm 5.973$ & \\
\hline Median & 67.00 & 65.00 & \\
\hline Range (min-max) & $60.00-80.00$ & $60.00-85.00$ & \\
\hline Height (m) & & & $0.0001^{*}$ \\
\hline Mean \pm Std & $1.60 \pm 0.067$ & $1.52 \pm 0.074$ & \\
\hline Median & 1.61 & 1.53 & \\
\hline Range (min-max) & $1.41-1.72$ & $1.34-1.76$ & \\
\hline Weight (kg) & & & $0.0001^{*}$ \\
\hline Mean \pm Std & $63.33 \pm 7.313$ & $52.95 \pm 6.653$ & \\
\hline Median & 64.30 & 52.20 & \\
\hline Range (min-max) & $46.30-79.00$ & $40.50-76.70$ & \\
\hline Body mass index $\left(\mathrm{kg} / \mathrm{m}^{2}\right)$ & & & $0.0001^{*}$ \\
\hline Mean \pm Std & $24.49 \pm 2.352$ & $22.71 \pm 2.269$ & \\
\hline Median & 23.80 & 22.50 & \\
\hline Range (min-max) & $18.80-30.10$ & $18.60-27.90$ & \\
\hline Body fat (\%) & & & $0.0001^{*}$ \\
\hline Mean \pm Std & $24.98 \pm 7.510$ & $33.05 \pm 5.150$ & \\
\hline Median & 7.51 & 33.00 & \\
\hline Range (min-max) & $12.00-47.30$ & $22.20-42.10$ & \\
\hline Skeletal muscle mass index $\left(\mathrm{kg} / \mathrm{m}^{2}\right)$ & & & $0.0001^{*}$ \\
\hline Mean \pm Std & $8.20 \pm 1.188$ & $6.43 \pm 0.629$ & \\
\hline Median & 1.41 & 6.36 & \\
\hline Range (min-max) & $6.25-10.97$ & 5.--9.23 & \\
\hline Hand grip strength (kg) & & & $0.0001^{*}$ \\
\hline Mean \pm Std & $23.67 \pm 5.278$ & $16.16 \pm 4.145$ & \\
\hline Median & 22.00 & 16.50 & \\
\hline Range (min-max) & $13.00-34.00$ & $10.00-29.00$ & \\
\hline Physical performance (m/s) & & & 0.056 \\
\hline Mean \pm Std & $0.91 \pm 0.492$ & $0.87 \pm 0.184$ & \\
\hline Median & 1.00 & 0.88 & \\
\hline Range (min-max) & $0.05-1.83$ & $0.37-1.42$ & \\
\hline
\end{tabular}

Significance: $\mathrm{p}<0.05$; ${ }^{*}$ refers to statistical significance 
Table 2 Correlation between Physical Performance, Body Fat, and BMI

\begin{tabular}{lcc}
\hline \multicolumn{1}{c}{ Variables } & r & p value \\
\hline PP vs Body Fat & -0.360 & $0.000^{*}$ \\
PP vs SMI & 0.210 & $0.031^{*}$ \\
PP vs BMI & 0.006 & 0.950 \\
PP vs Height & 0.150 & 0.125 \\
PP vs Weight & 0.112 & 0.253 \\
\hline
\end{tabular}

Significance: $\mathrm{p}<0.05$; $^{*}$ represents statistical significance; r: coefficient correlation; BMI: body mass index; PP: physical performance; SMI: skeletal muscle mass index

(Table 1). The characteristics of the participants in this previous cohort study showed that most participants are overweight $(48.3 \%)$ and eutrophic (39.2\%), which is similar to our study. The result of previous studies showed that muscle strength and body weight are the most significant mediators of the relationship between physical activity and UGS, ${ }^{8}$ but in our study, only muscle strength shows relation with physical performance.

Generally, it is known that elderly persons have lower muscle mass and greater fat mass as well as slower gait speed and reduced strength. The decline in physical performance occurs concurrently with age and body composition. While some studies have found that there is a positive relationship between muscle mass and physical performance in older adults, other studies have shown that there is no correlation between these two factors but rather, there is a more negative relation between fat mass and physical performance. ${ }^{9}$

During aging, there is a $5-25 \%$ decrease in resting metabolic rate. Muscle mass as the main determinant of resting metabolic rate will decrease throughout the aging, leading to body weight gain and fat accumulation, even with the unchanged dietary intake and exercise habits. Body fat gradually increases between 20-25 years of age, until about 65 years. Aging causes a condition called myosteatosis or fat infiltration into muscle. Muscle fat in the form of intraand extra-myocellular adipocytes (droplets of triglyceride) is embedded within and between muscle fibers resulting in increased storage of lipid droplets. Earlier studies relating to this study result showed that muscle fat infiltration has been observed to be associated with poorer strength and scores on performance tests, as well as the incident mobility disability. With
Table 3 Correlation between Physical Performance and Muscle Strength by Gender

\begin{tabular}{lcc}
\hline \multicolumn{1}{c}{ Gender } & r & p-value \\
\hline Male & 0.379 & $0.016^{*}$ \\
Female & 0.258 & $0.037^{*}$ \\
\hline
\end{tabular}

Significance: $\mathrm{p}<0.05$; * statistically significant; $r$ : coefficient correlation

the concomitant decline in lean body mass and bone tissues in aging, it may impact older adults function as aging continues. ${ }^{5,10}$

The accumulation of lipids in non-adipose tissue (ectopic) is a lipotoxic process that may occur long before an individual meets the criteria for obesity. Previous research has revealed a strong link between intermuscular adipose tissue and elevated concentrations of pro-inflammatory cytokines. Leptin and adiponectin are classic hormones (adipokines) secreted by adipose tissue that mediates chronic inflammation. Leptin stimulates the pro-inflammatory action of IL-6, IL-12, and TNF- $\alpha$. It is higher in women and proportionally increases with the increased fat tissue. ${ }^{11}$ Two to four-fold elevations in circulating levels of IL- 6 and TNF- $\alpha$, CRP, and serum amyloid A (SAA) are typically found in older adults when compared to the young, even in the absence of chronic diseases. Adipose tissue also demonstrates increased activation of intracellular kinases, such as c-jun N-terminal kinase and protein kinase $\mathrm{R}$, which can induce inflammation. ${ }^{12}$ Activators of inflammation such as inflammasome and the Toll-like receptors are activated in adipose tissue. In addition, inflammatory cells like macrophages and $\mathrm{T}$ cells infiltrate into adipose tissue. This condition further increases systemic inflammation, including in skeletal muscle. Aging is also associated with the increase of reactive oxygen species (ROS) in tissue and circulating levels, as well as the decline in antioxidant capacity. ROS activation of toll-like receptors on a variety of immune cells will activate the inflammatory cascade. $^{9,} 13$ This condition will promote and sustain low-grade chronic inflammation (LGCI) as the cause of the age-related decline in the proliferative rate of myoblasts. ${ }^{14} \mathrm{LGCI}$ is a state of persistent and unresolved inflammation where pro- and anti-inflammatory cytokines are elevated and inflammation is not resolved. It is associated with increased risk for disease, impaired muscle and bone quality resulting in poor physical functioning and mortality. ${ }^{14,15}$ 
Inflammatory cascade will contribute to direct effects on muscle catabolism that may contribute to loss of function via direct effects on muscle catabolism. A study found that there was an association between CRP, IL- 6 , and TNF- $\alpha$ in muscle wasting and physical function. The study found an inverse correlation between those inflammation markers with the synthesis rate of myosin heavy chain protein that may contribute to functional decline and physical disability through skeletal muscle protein content and loss of muscle mass and strength. The study result also supports earlier study that showed the correlation of better performance in older adults with the reduction of fat mass and percentage of body fat. ${ }^{16}$

The relationship between muscle mass and physical function has been inconsistent. A study found that muscle mass was not associated with physical performance in weak older adults. This study supports the association between muscle mass index and muscle strength with physical performance positively, but it may be caused by the characteristic of the participant that relatively in good physical performance level. In one study by Kim et al, it was found that in both genders, higher BMI and body fat percentage have been associated with poor physical function, whilst better physical function was related to overall appendicular lean mass. ${ }^{9}$ Increased muscle mass was associated with faster walk speed and stronger grip strength. Our study showed that both genders have the same result, except we did not find any association between BMI and physical performance (Table 2).

BMI was an accepted index for the detection of obesity. This study found that there is no correlation between BMI with physical performance, different from the previous finding in another study that shows that BMI is associated with physical performance ${ }^{17}$ One of the reasons may be caused by the mean of BMI subjects in this study that was classified as nourished or adequate in both genders (Table 1).

Muscle mass and muscle strength are positively correlated, independently of the associations of age and gender with muscle mass and strength. Although, certain comorbid medical conditions may modify the relationship between muscle mass and muscle strength. Measures of muscle strength may be of greater clinical importance in weak older adults than is muscle mass per se. ${ }^{18}$ Table 2 shows that there is a low positive correlation between handgrip strength and physical performance that measure with a speed of gait in men and women. There was even a significant difference in the handgrip strength in a different gender. It supports a similar study that shows a correlation between handgrip strength and functional mobility measured by the Timed Up-and-Go test. ${ }^{19}$

The positive relationship between muscle mass and physical performance is shown more clearly when functionality was measured with handgrip strength. In a clinical setting, handgrip strength is used as a tool to have a rapid indication of overall muscle strength. Handgrip strength is a good predictor of functional disability, and it can predict 5-year mortality in a specific population. ${ }^{6}$ Study was showed that handgrip strength and gait speed are independently associated with incident disability in Mexican older adults. ${ }^{20}$

Inconsistent findings regarding the relationship between body composition and physical performance persist. Considering both body fat and muscle mass, some studies supported that it is adiposity/obesity, not muscle mass, that became a stronger determinant of physical performance in older adults, and ASMI was not an explanatory factor of physical performance. ${ }^{6}$ Our result is aligned with the findings that body fat may become a simple indicator to predict physical performance in community-dwelling older adults.

This study has several limitations, one of which is that the study was a cross-sectional study, not a longitudinal study. The result of this study should be thoroughly interpreted because of the limited sample and utilization of BIA that even already validate but not as the gold standard for body composition measurement tools, such as DXA. Larger samples will allow greater extrapolation of data to the general population and increase the power of the study. Regardless of gait assessment as a parameter of physical performance that even being a quick, safe, and inexpensive and highly reliable measure but different study methodology making it difficult to compare among studies.

Physical performance is a strong predictor of mortality, hospitalization, and disability. In conclusion, this study shows that body composition and handgrip strength correlate with physical performance. Based on the finding, this study supports the measurement of body composition and muscle strength as an option that may become an indicator of future function decline, especially for walking capabilities in the community-dwelling older adults in Indonesia. 


\section{References}

1. Graham JE, Fisher SR, Bergés I-M, Kuo Y-F, Ostir GV. Walking speed threshold for classifying walking independence in hospitalized older adults. Physical therapy. 2010;90(11):1591-7.

2. Quiben MU, Hazuda HP. Factors contributing to $50-\mathrm{ft}$ walking speed and observed ethnic differences in older communitydwelling Mexican Americans and European Americans. Phys Ther. 2015;95(6):871-83.

3. Inoue $\mathrm{W}$, Ikezoe $\mathrm{T}$, Tsuboyama $\mathrm{T}$, Sato I, Malinowska KB, Kawaguchi T, et al. Are there different factors affecting walking speed and gait cycle variability between men and women in community-dwelling older adults?.Aging Clin Exp Res. 2017;29(2):21522.

4. Nobuyuki $M$, Motohiko $M$, Izumi T, Noriko S, Tomohiro H, Takeyuki N. Relationship between muscle strength and anthropometric, body composition parameters in Japanese adolescents. Health. 2012;4(1):1-5.

5. Harbuwono DS., Pramono LA, Yunir E, Subekti I. Obesity and central obesity in Indonesia: evidence from a national health survey. Med J Indones. 2018.27(2):114-20.

6. Shin H, Panton LB, Dutton GR, Ilich JZ. Relationship of physical performance with body composition and bone mineral density in individuals over 60 years of age: a systematic review. J Aging Res. 2011;2011:191896.

7. Busch TA, Duarte YA, Nunes DP, Lebrão ML, Naslavsky MS, Rodrigues AS, et al. Factors associated with lower gait speed among the elderly living in a developing country: a cross sectional population-based study. BMC Geriatrics. 2015;15:35.

8. Barbat-Artigas S, Carvalho LP, Rolland Y, Vellas B, Aubertin-Leheudre M. Muscle strength and body weight mediate the relationship between physical activity and usual gait speed. J Am Med Dir Assoc. 2016;17(11):1031-6.

9. Kim S, Leng XI, Kritchevsky SB. Body composition and physical function in older adults with various comorbidities. Innov Aging. 2017;1(1):igx008.

10. JafariNasabian P, Inglis JE, Reilly W, Kelly OJ, Ilich JZ. Aging human body: changes in bone, muscle and body fat with consequent changes in nutrient intake. J Endocrinol.
2017;234(1):R37-51.

11. Pires A, Martins P, Pereira AM, Marinho J, Silva PV, Marques $M$, et al. Proinflammatory triggers in childhood obesity: correlation between leptin, adiponectin and high-sensitivity C-reactive protein in a group of obese Portuguese children. Revista Portuguesa de Cardiologia. 2014;33(11):691-7.

12. Nakamura T, Furuhashi M, Li P, Cao H, Tuncman G, Sonenberg N, et al. DoublestrandedRNA-dependentprotein kinase links pathogen sensing with stress and metabolic homeostasis. Cell. 2010;140(3):338-48.

13. Woods JA, Wilund KR, Martin SA, Kistler BM. Exercise, inflammation and aging. Aging and disease. 2012;3(1):130-40.

14. Ilich JZ, Kelly OJ, Kim Y, Spicer MT. Lowgrade chronic inflammation perpetuated by modern diet as a promoter of obesity and osteoporosis. Arh Hig Rada Toksikol. 2014;65(2):139-48.

15. Zoico E, Rossi A, Di Francesco V, Sepe A, Olioso D, Pizzini F, et al. Adipose tissue infiltration in skeletal muscle of healthy elderly men: relationships with body composition, insulin resistance, and inflammation at the systemic and tissue level. J Gerontol A Biol Sci Med Sci. 2010;65(3):295-9.

16. Falsarella GR, Gasparotto LPR, Barcelos CC, Coimbra IB, Moretto MC, Pascoa MA, et al. Body composition as a frailty marker for the elderly community. Clin Interv Aging. 2015;10:1661-6.

17. Shen S, Li J, Guo Q, Zhang W, Wang X, Fu L, et al. Body mass index is associated with physical performance in suburb-dwelling older Chinese: A cross-sectional study. PLoS One. 2015;10(3):e0119914.

18. Kim K-E, Jang S-n, Lim S, Park YJ, Paik N-J, Kim $\mathrm{KW}$, et al. Relationship between muscle mass and physical performance: is it the same in older adults with weak muscle strength?. . Age Ageing. 2012;41(6):799-803.

19. Pratama I, Setiati S, editors. Correlation between hand grip strength and functional mobility in elderly patients. Journal of Physics: Conference Series; 2018: IOP Publishing.

20. López-Teros T, Gutiérrez-Robledo L, PérezZepeda M. Gait speed and handgrip strength as predictors of incident disability in Mexican older adults. J Frailty Aging. 2014;3(2):10912. 